\title{
A child patient who ingested multiple magnets: Case report
}

\author{
Çoklu mıknatıs yutan çocuk hasta: Olgu sunumu
}

\author{
(D) Melike ARSLAN ${ }^{1}$, D Metehan UYAR², (D) Selim Can PEKER², D Necati BALAMTEKIN \\ 'University of Health Sciences, Gülhane Training and Research Hospital, Department of Child Health and Diseases, Division of \\ Pediatric Gastroenterology, Ankara
}

${ }^{2}$ University of Health Sciences, Gülhane Training and Research Hospital, Ankara

\begin{abstract}
Foreign body ingestion is common in the pediatric age group. Swallowed foreign objects show different features, especially coins, small toys and toy parts, magnets, and batteries. Coins are the most frequently swallowed foreign objects, followed by toys and toy parts. Magnets are mostly found in toys and other products. Swallowing single magnet does not often cause complications but swallowing multiple magnets or magnets attached to a metal objects could pull the intestinal walls together and cause volvulus, fistulas, and peritonitis. Medical diagnostic display techniques play an important role in cases of foreign body aspiration and swallowing observed in children. In foreign body ingestion, the main goals are rapid identification and positioning for an effective treatment. Prompt diagnosis and treatment are critical for the immediate removal of swallowed objects. Highly adhered treatments may have a high risk of mortality and morbidity. Here, we present a case of a five-year old girl who was brought to the pediatric emergency department with a suspicion of ingesting foreign objects.
\end{abstract}

Keywords: Multiple magnet ingestion, intestinal foreign body, child

\section{INTRODUCTION}

Foreign body ingestion is one of the common clinical problem in children between 6 months and 5 years of age who are admitted to the pediatric emergency department. Coins, small batteries, magnets and jewelleries are most frequently observed in patients presenting with foreign body ingestion. \%75 of foreign body swallowings are seen in children (1). According to the studies conducted in the United States, the annual incidence of pediatric emergency visits due to magnet ingestion was found 3.75 / 10.000 between 2002-2011 (2).

In most of the cases, single magnet swallowing does not cause a complication. The main reason is; single magnet swallow is not cause any problem, cause it behaves

Correspondence: Melike ARSLAN

Gülhane Training and Research Hospital

Department of Child Health and Diseases, Divison of Pediatric

Gastroenterology, Etlik-Ankara·E-mail: melikearslan190@gmail.com
Yabancı cisim yutulması pediatrik yaş grubunda yaygındır. Yutulan yabancı cisimler oldukça farklılık gösterir ve özellikle; madeni paralar, küçük oyuncaklar, mıknatıslar ve pilleri içerirler. Madeni para çocuk hastalarda en sık yutulan yabancı cisim olup ikinci sırada oyuncaklar ve oyuncak parçaları gelir. Mıknatıslara çoğunlukla oyuncaklar ve diğer ürünlerden ulaşılır. Mıknatısların tekli yutulmaları çoğunlukla herhangi bir komplikasyona neden olmazken çoklu veya beraberinde metal cisimlerle yutulması durumunda bağırsak duvarlarını birbirine çekerek volvulusa, fistüllere ve peritonite neden olabilir. Görüntüleme yöntemleri çocuklarda gözlenen yabancı cisim aspire edilmesi ve yutulması vakalarında tanı konmasında önemli bir rol oynar. Yabancı cisim yutmalarında, cismin hızlı tanımlanması ve yerinin belirlenmesi etkili bir tedavi için ana unsurlar arasındadır. Hızlı tanı ve tedavi yutulan cisimlerin acil olarak uzaklaştırılması için kritik bir öneme sahiptir. Geç kalınan tedaviler mortalite ve morbidite açısından yüksek risk taşımaktadır. Bu makalede, çoklu mıknatıs yutma şüphesi ile acil servise başvuran beş yaşında kız hasta sunulmuştur.

Anahtar kelimeler: Çoklu mıknatıs yutma, bağırsakta yabancı cisim, çocuk

like an isolated object and discharged from the body by silently moving without harming the gastrointestinal system $(3,4)$. Multiple magnets or metal objects with magnets ingestion is increase mortality and morbidity rates. The main reasons that increase the risks are; intestinal obstruction, volvulus, fistula, necrosis or perforation due to the attraction of magnets to the intestinal walls $(3,4)$.

\section{CASE REPORT}

A five-years-old girl was brought to the emergency room within half an hour after swallowing a foreign body with the complaint of magnet swallowing while playing. It was learned that she swallowed four magnets from her

Arslan M, Uyar M, Peker SC, et al. A child patient who ingested multiple magnets: Case report. The Turkish Journal of Academic Gastroenterology 2021;20:181-184. DOI: 10.17941/agd.1055252

Manuscript received: 26.08.2021 • Accepted: 07.10.2021 
family. Vital signs of the patient when she admitted are; pulse: $78 \mathrm{~min}$, body temperature $36.9{ }^{\circ} \mathrm{C}$, respiratory rate: 13 / $\min , \mathrm{spO}_{2}$ : 99. On physical examination, her body weight was $16 \mathrm{~kg}(10-25 \mathrm{p})$ and her height was $104 \mathrm{~cm} \mathrm{(10} \mathrm{-} 25$ p). There was no pathological finding on system examination. There was no feature in her personal background and family history. In the complete blood count, hemoglobin was $12.1 \mathrm{~g} / \mathrm{dl}$, white blood cell was $7400 / \mathrm{mm}^{3}$, and thrombocyte was $350.000 / \mathrm{mm}^{3}$. In routine biochemical examinations, alanine aminotransferase was measured as $22 \mathrm{U} / \mathrm{L}$, aspartate aminotransferase $34 \mathrm{U} / \mathrm{L}$, urea: $21 \mathrm{mg} / \mathrm{dl}$, creatine: $0.51 \mathrm{mg} / \mathrm{dl}$, sodium: $138 \mathrm{mmol} / \mathrm{l}$, potassium: $4.32 \mathrm{mmol} / \mathrm{l}$. In the standing direct abdominal radiography of the patient taken for diagnosis; in the median line of the abdomen, 4 adjacent magnets approximately $1 \mathrm{~cm}$ in size were observed at a level compatible with the small intestine (Figure 1). The patient was admitted to the pediatric surgery service for follow-up and treatment. On admission to the service, a contrast-enhanced passage radiograph was taken to determine the location of the foreign body clearly, and it

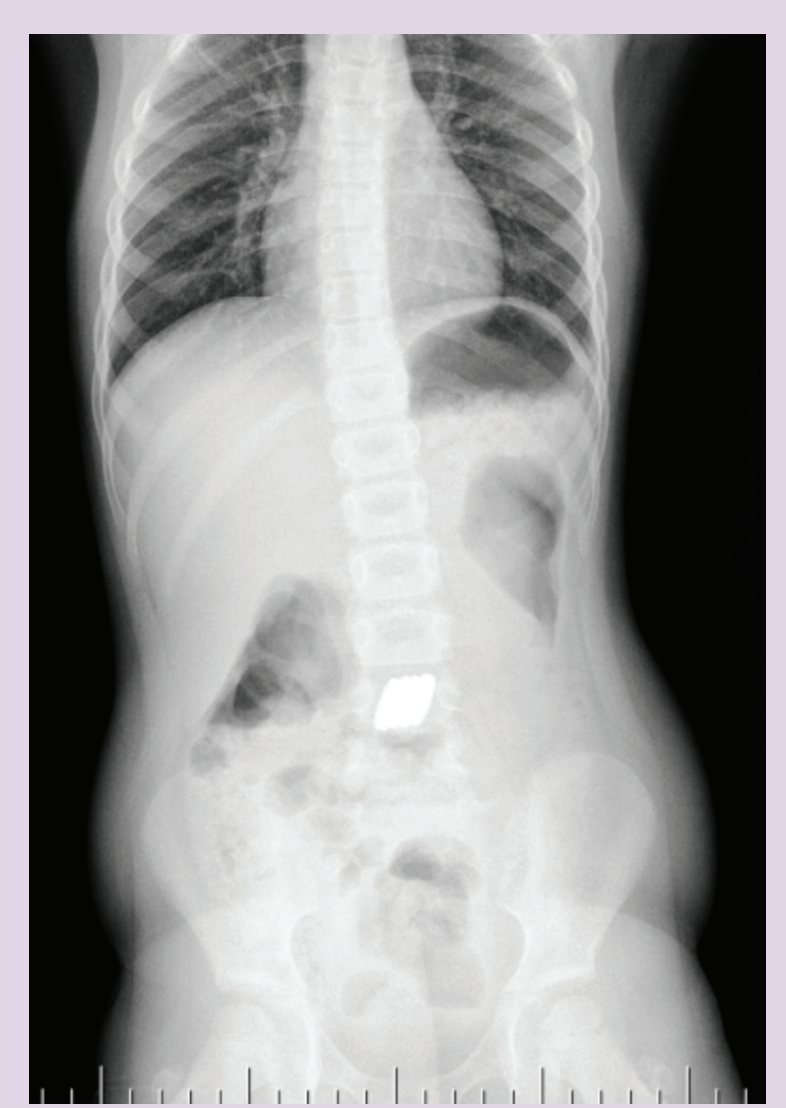

Figure 1. Four adjacent magnets approximately $1 \mathrm{~cm}$ in size were observed at a level compatible with the small intestine. was found that the magnets were at the fundus level of the stomach (Figure 2). Thereupon, upper gastrointestinal system endoscopy was performed with the Olympus QX-260 device by pediatric gastroenterologist. During the endoscopy, 4 stuck magnets were observed in the fundus of the stomach and the magnets were removed with flare snare without any complication (Figures 3-4). After the removal of the foreign body, the patient, did not have any complication, and discharged on the 2nd day of hospitalization with recommendations. An informed consent form was obtained from the family of the patient.

\section{DISCUSSION}

Foreign body ingestion, which is more common in young children than in the rest of the population, usually occurs unintentionally. Children are prone to swallowing toys due to their small size and brightness. Most of the magnetic objects that are swallowed are parts of toy sets along with necklaces with magnetic parts, magnet earrings, magnets from board games, refrigerator magnets,

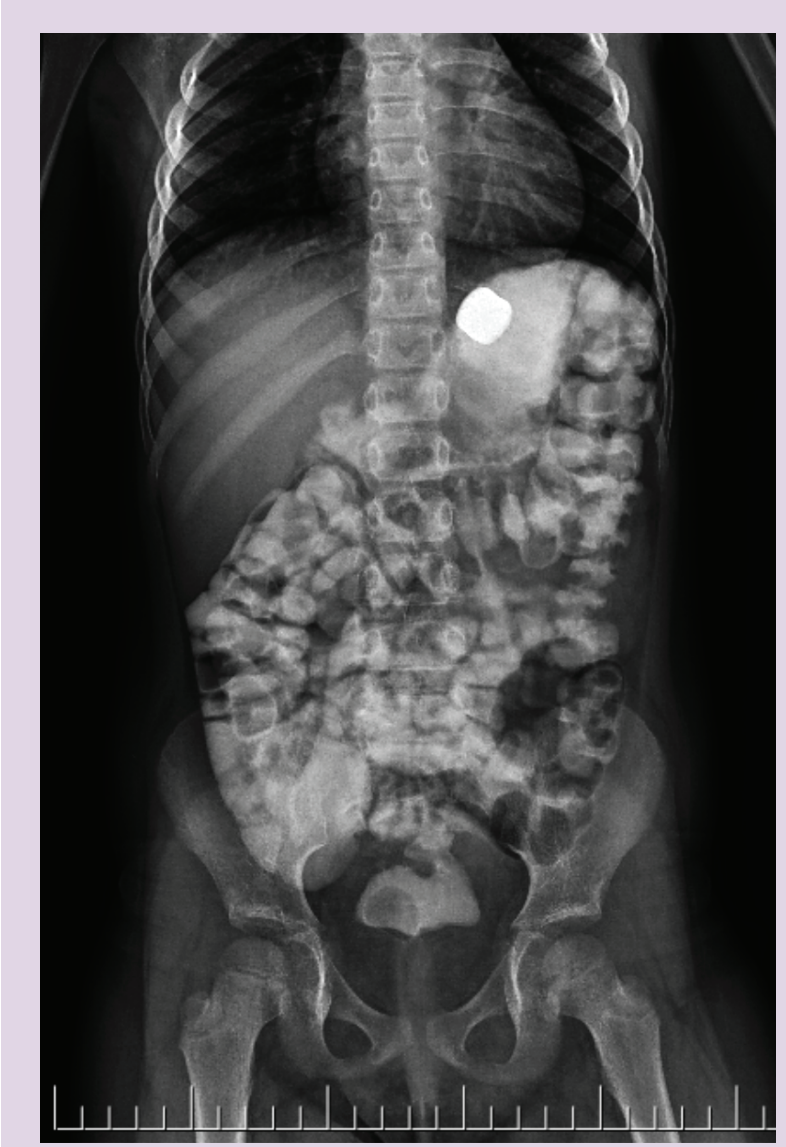

Figure 2. Contrast-enhanced passage radiograph was taken to determine the location of the foreign body clearly. 

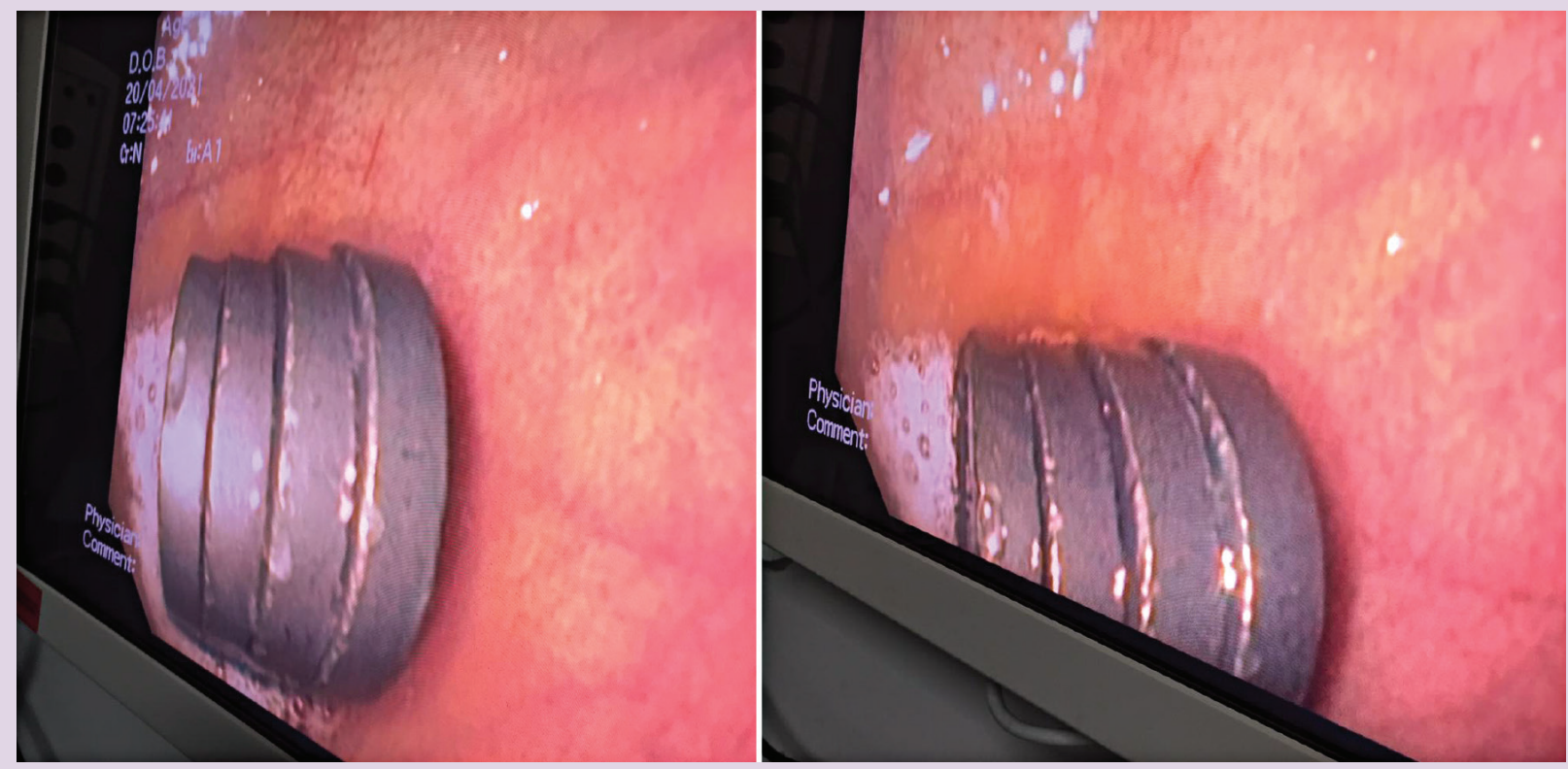

Figure 3-4. During the endoscopy, 4 stuck magnets were observed in the fundus of the stomach and the magnets were removed with flare snare without any complication.

bracelet pieces, alphabet learning tools and piercings (5). Our case, on the other hand, was a 5-year-old girl and was brought to the emergency room with the complaint of magnet swallowing while playing.

In $80-90 \%$ of the cases, the foreign body is thrown out after entering the small intestine without any signs or symptoms (6). Approximately $10-20 \%$ of swallowed foreign bodies are removed endoscopically, while $1 \%$ is removed by a surgical operation (7). The approach in pediatric cases with the possibility of foreign body swallowing determined by several parameters; type of the object, the time elapsed after swallowing and the clinical condition of the patient (7). Although it has been reported that the time between magnet intake and the development of complications is between a few days and 7 days, there are also studies indicating that this interval may be longer $(8,9)$.

Except for parents and caregivers who witness ingestion, diagnosis may be delayed because most children are asymptomatic rather than show nonspecific findings such as feeding problems or irritability. Some parents, on the other hand, do not consult a doctor because they think that the swallowed objects will be thrown spontaneously, although they witness swallowing (9). Symptoms generally occur according to the anatomical location of the swallowed object. It can cause a variety of symptoms including drooling in the esophagus, dysphagia, refusal of food, feeling of choking, and/or chest pain $(10,11)$.
In the stomach and intestines, vomiting, haematemesis, or abdominal pain may be observed when symptoms are observed, although objects do not cause mucosal injury or obstruction (11). In our case, who came to our emergency department with the suspicion of magnet swallowing, no clinical finding was observed because of the short time interval and the location of the foreign body.

In the case of magnet ingestion, the first way to follow is to take the correct anamnesis. It is necessary to take X-rays, including abdominal lateral views, and to determine whether the magnet swallowed is single or multiple. If the magnets are in a position that can be accessed by endoscopy, endoscopic removal of the magnets should be preferred (12). Since single magnet swallows are counted from nonmagnetic swallows, they are got over beyond any complications. If the patient is swallowed a single magnet, the patient should be followed up with a serial X-ray until the magnet is expelled. In multiple magnet swallows, if the magnets are in the stomach, they should be removed endoscopically by a pediatric gastroenterologist. If endoscopic removal fails, pediatric surgery should be consulted for removal. If magnets have passed through the stomach in multiple magnet swallows, the management is divided into two as symptomatic or asymptomatic. In symptomatic cases, pediatric surgery is practiced to remove magnets. In asymptomatic cases, magnets are removed by endoscopy or colonoscopy. After successful removal of the ingested magnets, the patient is kept under observation in the hospital for tole- 
rance to the food. In cases where there is no endoscopic removal, the magnets are followed according to whether they are progressing on the X-ray. Surgical intervention is performed for the magnet that is stocked down while the advancing magnet is followed by X-ray (12). Our case presented with multiple magnet swallowing and was removed endoscopically by a pediatric gastroenterologist since the foreign body was viewed at the fundus level of the stomach in the asymptomatic patient.

\section{REFERENCES}

1. George AT, Motiwale S. Magnets, children and the bowel: A dangerous attraction? World J Gastroenterol 2012;18:5324-8.

2. Abbas MI, Oliva-Hemker M, Choi J, et al. Magnet ingestions in children presenting to US emergency departments, 2002-2011. J Pediatr Gastroenterol Nutr 2013;57:18-22.

3. Butterworth J, Feltis B. Toy magnet ingestion in children: revising the algorithm. J Pediatr Surg 2007;42:e3-5.

4. Prevalence, clinical features and management of pediatric magnetic foreign body ingestions - PubMed n.d. https://pubmed.ncbi.nlm. nih.gov/22727803/ (accessed April 22, 2021).

5. Oestreich AE. Worldwide survey of damage from swallowing multiple magnets. Pediatr Radiol 2009;39:142-7.

6. Uchida K, Otake K, Iwata $T$, et al. Ingestion of multiple magnets: hazardous foreign bodies for children. Pediatr Radiol 2006;36:2634.
Magnets are one of the substances that are swallowed by patients presenting with foreign body ingestion. Magnets can be swallowed singly or multiple times. To prevent pediatric foreign body ingestion, it is important to remove potentially hazardous items and toys from the reach of young children and appropriate supervision are essential.

Conflicts of interest: All authors declare no conflicts of interest.

7. Gurevich $Y$, Sahn B, Weinstein T. Foreign body ingestion in pediatric patients. Curr Opin Pediatr 2018;30:677-82.

8. Nui A, Hirama T, Katsuramaki T, et al. An intestinal volvulus caused by multiple magnet ingestion: an unexpected risk in children. J Pediatr Surg 2005;40:e9-11.

9. Corduk N, Odabas SE, Sarioglu-Buke A. Intestinal perforation caused by multiple magnet ingestion. Afr J Paediatr Surg 2014;11:84-6.

10. Kim JE, Ryoo SM, Kim YJ, et al. [Incidence and Clinical Features of Esophageal Perforation Caused by Ingested Foreign Body]. Korean J Gastroenterol 2015;66:255-60.

11. Little DC, Shah SR, St Peter SD, et al. Esophageal foreign bodies in the pediatric population: our first 500 cases. J Pediatr Surg 2006;41:914-8.

12. Hussain SZ, Bousvaros A, Gilger M, et al. Management of ingested magnets in children. J Pediatr Gastroenterol Nutr 2012;55:239-42. 